\title{
ОБЪЕКТ НАЛОГООБЛОЖЕНИЯ КАК ЭЛЕМЕНТ НАЛОГА НА ИМУЩЕСТВО ФИЗИЧЕСКИХ ЛИЦ
}

\author{
(c) 2019 Бабаян Зарине Мкртичевна \\ аспирант кафедры правого обеспечения экономической деятельности \\ Саратовский социально-экономический институт (филиал) РЭУ имени Г.В. Плеханова, Россия, Саратов \\ E-mail: zarine.k@yandex.ru
}

С объектом налогообложения, а точнее с нарушением правил его учета, связывается и состав отдельного налогового правонарушения, что тоже подчеркивает его важность в механизме правового регулирования сферы налогообложения. Объект налогообложения как элемент юридической конструкции налога очень значим для целей установления, введения, и взимания налогов, что указывает на необходимость изучения сущности этого понятия, совершенствование понятийного аппарата, связанного с названным элементом.

Ключевые слова: объект налогообложения, налог на имущество физических лиц, НК РФ, налоги, законность.

В настоящее время вопросы теоретического определения объекта налогообложения являются актуальными уже в силу того, что данный элемент указывает, с чего берется тот или иной налог.

Известно, что налоги являются существенным признаком государства, что нашло свое отражение и в Конституции РФ. В связи с этим Конституционный Суд РФ в своих решениях постоянно подчеркивает значение налоговых платежей как экономической основы деятельности Российского государства.

В Налоговом кодексе РФ (далее - НК РФ) положения Основного Закона детализированы относительно законности установления налогов, в том числе в части закрепления в законах и решениях о налогах вместе с налогоплательщиками также объектов налогообложения и иных элементов налогообложения, то есть речь идет об определенной юридической конструкции налога.

Налог на имущество физических лиц является прямым налогом местного уровня [4, с. 152]. Под имуществом в целях налогообложения в целом понимаются виды объектов гражданских прав (за исключением имущественных прав), относящихся к имуществу в соответствии с ГК РФ, то есть применяется в данном случае терминология гражданского права (п. 2 ст. 38 НК РФ). Имущество характеризует товар, как реализуемое либо предназначенное для реализации. При этом указывается, что к товарам может быть отнесено иное имущество, определяемое в соот- ветствии с таможенным законодательством (п. 3 ст. 38 НК РФ).

Трофимов С.В. указывает, что при принятии НК РФ термин «имущество» не отличался применительно к налоговым отношениям от аналогичного понятия в ГК РФ. Но в 1999 году в ст. 38 НК РФ были внесены изменения, согласно которым имущественные права исключены из содержания имущества, что однако не коснулось норм части второй НК РФ [5, с. 19].

В настоящее время к числу регионов, которые ввели кадастровую оценку стоимости имущества, относятся 72 субъекта РФ. Таким образом, на территориях 13 субъектов РФ пока применяется инвентаризационная стоимость имущества, но с учетом коэффициента-дефлятора, устанавливаемого Министерством экономического развития РФ (Свердловская область, Томская область, Республика Крым, город Севастополь). На 2018 год коэффициент составляет 1,481 относительно инвентаризационной стоимости по состоянию на 1 марта 2013 года. С каждым годом показатель коэффициента увеличивается, к примеру, в 2017 году он составлял 1,425.

В ранее действовавшем Законе РФ от 9 декабря 1991 г. № 2003-1 «О налогах на имущество физических лиц» в качестве объекта обложения данным налогом также являлось имущество, принадлежавшее физическим лицам на праве собственности (п. 1 ст. 1).

При сравнении поимущественного налогообложения в Российской Федерации и иных странах стоит указать, что на основании ст. 323 
раздела XIII «Налог на имущество» Налогового кодекса Кыргызской Республики в Кыргызстане налог на имущество не подразделяется на отдельные налоги для организации и физических лиц, являясь единым для обеих категорий плательщиков. Объектом налогообложения является имущество, находящееся:

- в государственной собственности, а также закрепленное за государственными предприятиями (на праве хозяйственного ведения или на праве оперативного управления) и за учреждениями (на праве оперативного управления);

- в муниципальной собственности, а также закрепленное за муниципальным предприятием (на праве хозяйственного ведения) и за учреждениями (на праве оперативного управления);

- в частной собственности.

В соответствии со статьей 405 действовавшего до 31 декабря 2017 года Кодекса Республики Казахстан «О налогах и других обязательных платежах в бюджет» от 10 декабря 2008 г. № 99IV объектом обложения налогом на имущество физических лиц являются находящиеся на территории государства жилища, здания, дачные постройки, гаражи и иные строения, сооружения, помещения, принадлежащие им на праве собственности.

Изложенное показывает, что в странах бывшего СССР имущественное налогообложение физических лиц обусловлено либо единым налогом на имущество для организаций и физических лиц (налогом на недвижимость, налогом на недвижимое имущество), либо отдельным для указанной категории налогоплательщиков налогом.

Если рассматривать дальнее зарубежье, то, в частности, налог на недвижимость Швейцарии является кантональным и, соответственно, регламентируется на этом уровне. А на Кипре для привлечения инвесторов-физических лиц налога на имущество был отменен с 1 января 2017 года. Ранее же им облагалась также стоимость жилой недвижимости [2, с. 79].

Стоит обратить внимание, что по российскому законодательству о налогах и сборах под объект обложения налогом не подпадает имущество, временно переведенное на консервацию.

В России также проводился эксперимент, связанный с использованием единого налога на недвижимость. В частности, 20 июля 1997 г. был принят Федеральный закон «О проведении экс- перимента по налогообложению недвижимости в городах Великом Новгороде и Твери» № 110Ф3. В рамках эксперимента на территориях названных городов в период с 1997 по 2005 г.г. вместо налога на имущество предприятий, налога на имущество физических лиц (за исключение налога на транспортные средства) и земельного налога взимался единый налог на недвижимость. Это было связано с тем, что поступления от имущественных налогов не обеспечивали стабильности поступлений в бюджетную систему, а налоговая база недвижимого имущества не соответствовала рыночным ценам. Налог планировался как местный, а налоговая база рассчитывалась из рыночной стоимости объектов налогообложения. Хотя эксперимент был признан успешным, налогообложение организаций и физических лиц в России сегодня осуществляется с использованием отдельных имущественных налогов. Тем не менее, сущность единого налога на недвижимость в других странах связывается с большей эффективностью его администрирования, снижением издержек на взимание и упрощением для налогоплательщиков процесса уплаты имущественных налогов в форме единого платежа.

Целесообразно указать, что от уплаты налога освобождены индивидуальные предприниматели, применяющие специальные налоговые режимы: ЕСХН (п. 3 ст. 346.1 НК РФ), УСН (п. 3 ст. 346.11 НК РФ), ЕНВД (п. 4 ст. 346.26 НК РФ) или патентную систему налогообложения (п. 10 ст. 346.43 НК РФ). Но это правило касается только имущества, применяемого для предпринимательской деятельности.

Как отмечают Погодина И.В. и Борисова А.А. в целом в мировой практике применяются несколько подходов в оценке имущества. Стоимость имущества определяется исходя из цены сделок с аналогичными объектами в США и Японии. Стоит отметить, что в России в настоящее время нет единого государственного источника информации о сделках на рынке недвижимости, поэтому данный способ не используется. По мнению авторов, наиболее справедливыми является сочетание затратного и сравнительного подхода [3, с. 25]. Этот вывод видится справедливым, поскольку позволяет оценивать имущество для целей налогообложения с учетом износа, то есть уменьшать его кадастровую либо инвентаризационную стоимость, к которой применяется ежегодный коэффициент-дефлятор. 
Следует оговорить, что закрепление различных объектов налогообложения не означает одинаковое применение по отношению к ним налоговых льгот. Так, под них не подпадают объекты, чья кадастровая стоимость превышает 300 млн. руб. (пп. 2 п. 2 ст. 406 НК РФ).

Уже упоминалось, что на основании ст. 401 НК РФ объектом налогообложения признаются жилой дом, жилое помещение (квартира, комната). При этом для установления указанных объектов необходимо обратиться к Жилищному кодексу РФ (далее - ЖК РФ).

Здесь необходимо обратить внимание на очень важную проблему, что согласно п. 4 ст. 15 ЖК РФ жилое помещение может быть признано непригодным для проживания по основаниям и в порядке, которые установлены Правительством РФ. Однако в Налоговом кодексе РФ нет упоминаний о таком возможном характере жилых помещений, которые, по сути, не могут использоваться по прямому назначению, но будут облагаться налогом в качестве объекта налогообложения.

Важно также указать, что, как отмечают специалисты, объектом по налогу являются не все изолированные помещения, а лишь квартира и комната, что подтверждается отдельным выделением среди объектов жилых домов. Таким образом, другие объекты, являющимися жилыми помещениями согласно жилищному законодательству, объектом налогообложения не будут. То есть часть жилого дома и часть квартиры не представляют собой самостоятельный объект обложения. В качестве примера можно привести законодательное закрепление в п. 6 ст. 403 НК РФ, что налоговая база относительно единого недвижимого комплекса, в состав которого входит хотя бы один жилой дом, определяется в качестве его кадастровой стоимости, уменьшенной на 1 млн. руб. Тем самым в наличии обособление жилых домов от иных изолирован- ных помещений, как это сделано и в отношении квартир и комнат [1, с. 66]. Стоит отметить, что дефиниций таких объектов налогообложения, как: гараж и машино-место,- до настоящего времени в законодательстве о налогах и сборах нет. К примеру, понятие «машино-место» закреплено в п. 29 ст. 1 Градостроительного кодекса РФ. А определение гаража до сих пор отсутствует в каком-либо федеральном законодательстве, присутствуя в некоторых актах налоговых органов. Нет в НК РФ и дефиниций понятий хозяйственное строение или сооружение, как и в ином отраслевом законодательстве.

Тем самым в качестве вывода можно констатировать, что для определения налоговой базы относительно имущества физических лиц как объекта налогообложения целесообразно использовать затратно-сравнительный способ оценки имущества, что дает возможность оценивать его с учетом износа, то есть уменьшать его кадастровую либо инвентаризационную стоимость, к которой применяется ежегодный коэффициент-дефлятор. Также необходимо внести дополнения в ст. 401 НК РФ, закрепив, что объектом налогообложения признается не просто жилой дом, квартира и комната, а пригодные именно для проживания. Целесообразно закрепить в НК РФ дефиниции таких понятий, как: машино-место; гараж, хозяйственное строение, хозяйственное сооружение. Имеет смысл вернуться к продолжению эксперимента по использованию единого налога на недвижимость вместо налога на имущество организаций, налога на имущество физических лиц и земельного налога с целью повышения эффективности налогового администрирования, снижения издержек на взимание и упрощения для налогоплательщиков процесса уплаты имущественных налогов в форме единого платежа, объектом которого были бы здания, сооружения и иное недвижимое имущество, земельные участки.

\section{Библиографический список}

1. Зрелов А. Налог на имущество физических лиц: парад коллизий // Налоговый вестник. 2014. № 12. С. 66-79.

2. Мясников О. Зарубежные налоговые юрисдикции, подходящие для жизни и инвестиций // Налоговый вестник - Консультации. Разъяснения. Мнения. 2017. № 10. С. 79-87.

3. Погодина И.В., Борисова А.А. Налогообложение недвижимого имущества: проблемы и перспективы // Налоги-журнал. 2015. № 5. С. 25-28.

4. Попов В.В. Вопросы реализации прав муниципальных образований в сфере налогообложения // Вестник Саратовской государственной академии права. 2010. № 5 (75). С. 152-154.

5. Трофимов С.В. Правовой режим имущества в налоговом законодательстве РФ // Финансовое право. 2015. № 2. C. 19. 